\title{
A Comparative Analysis of Indonesia's KPK and Hong Kong ICAC in Eradicating Corruption
}

\author{
Ridwan Arifin ${ }^{\star}$; Rodiyah ${ }^{\star \star}$; Fitria Puspita ${ }^{\star \star \star}$ \\ Faculty of Law, Universitas Negeri Semarang \\ ^ridwan.arifin@mail.unnes.ac.id

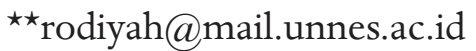

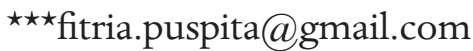

\section{Abstract}

This article seeks to discusses anti-corruption policies in Indonesia and Hong Kong. This research arises from the phenomenon of corruption that has become widespread in Indonesia and seems to be a never-ending problem that has caused great damage in all sectors of life. It's not only a matter of how much the state loss or corrupt modus operandi that is even more sophisticated and even makes Indonesia one of the highest-ranking countries in corruption cases, but it is also a matter of law enforcement whihch is less smart in handling corruption cases themselves. On the other hand, reportedly having a different approach in combating corruption, Hong Kong is considered to have been successful in carrying out its duties. With comparative study, this article will elaborate various patterns of work conducted by anti-corruption institutions in Indonesia and Hong Kong, namely the Corruption Eradication Commission (KPK) and the Independent Commission Against Corruption (ICAC).

Keywords: work pattern; corruption; Corruption Eradication Commission; Independent Commission against Corruption. 


\section{A. Introduction}

The problem of corruption has occurred in Indonesia since the colonial period to the present and still continue to exist after Indonesia's independence going through various eras of Indonesia's governments starting from the Old Order, the New Order, to the Reform Era. Since the reign of the New Order, the government of Indonesia has actually implemented strategies to tackle corruption, although one might wonder whether the strategy is based on the intention to seek political support, improve the positive image of the government or a real will to eradicate the corruption. ${ }^{1}$ During the Old Order, the government formed a team and an institution to eradicate corruption, but all did not work properly and ran smoothly. During the 2003 reformation period the government had made major changes based on Law Number 30 of 2002 challenging the Corruption Eradication Commission (KPK). ${ }^{2}$ It is an institution whose main task is to eradicate corruption in a professional, intensive and sustainable manner. In addition, the KPK is expected to become a trigger mechanism, which is a driver for efforts to eradicate corruption within institutions outside the KPK to be more effective and efficient. ${ }^{3}$

Despite the KPK's inception, however, corruption and scandal cases continue to emerge for years as one may clearly see an example of the Century case. This case was very shocking for the community at the time to find how it caused a loss as much as Rp. 6.7 trillion. This

1 Fahri Hamzah, Demokrasi, Transisi, Korupsi (Democracy, Transition, Corruption), Jakarta: Gudang Penerbit, 2012, p. 16-20; Djoko Pamungkas, How Police Overcomes Money Laundering? Study Analysis of Role of Central Java Regional Police Department on Money Laundering Case. Journal of Law and Legal Reform, 1(1), 2019, 23-30. https:// doi.org/10.15294/law \& legal reform.v1i1.35416; Alif Kharismadohan, Mens Rea and State Loses on Corruption Cases: An Analysis of Corruption Court Judgment of Semarang. Journal of Law and Legal Reform, 1(1), 2019, 61-74. https: / / doi. org/10.15294/law \& legal reform.v1i1.35407

2 Boesono Soedarso, Latar Belakang Sejarah dan Kultural Korupsi di Indonesia (The Historical and Cultural Background of Corruption in Indonesia), Jakarta: Universitas Indonesia, 2009.

3 Komisi Pemberantasan Korupsi, Memahami Untuk Membasmi (Understanding to Eradicate), Jakarta: Komisi Pemberantasan Korupsi, 2006. 
case originated from the Bank Century when experiencing difficulties in its finances. Being concerned that the Bank was going towards bankruptcy and might result in a systematically worst situation, the government provided financial assistance to the Bank. This case was quite complicated because of the alleged involvement of managers who were holding positions in government, which automatically had led to political constellation and caused uncertainty. This case was also linked to the issue of weakening the KPK and the involvement of Indonesian Police (POLRI) officials. ${ }^{4}$ In addition to the Bank scandal, another case that also attracted public attention was the e-KTP Corruption. The e-KTP corruption case was related to the procurement of an electronic ID card that had occurred since 2010. At first, the project went smoothly with supervision from the KPK (Corruption Eradication Commission), BPK and BPKP (Financial and Development Supervisory Agency) requested by Gamawan Fauzi (who was the Home Affairs Minister at the time). ${ }^{5}$

However, the condition continued to occur since the tender auction of e-KTP projects that made various parties both from KPPU (Business Competition Supervisory Commission), Government Watch, Police agency, the Cross Peruri Consortium and even the KPK (Corruption Eradication Commission) suspected that corruption had occurred. Therefore, the KPK conducted various investigations to find out the truth of this case and its mastermind. Through the evidence found and through the testimonies of witnesses, the KPK found the fact that corruption occurred which resulted in loss as much as Rp. 2,314 Trillion. Having conducted various investigations since 2013, the KPK finally decided number of suspects. Some of whom are officials of the Ministry of Home Affairs and officials of the House of Representatives. They were Sugiharto, Irman, Andi Narogong, Markus Nari, Anang Sugiana and Setya Novanto. The last

4 Fahri Hamzah, Kemana Ujung Century?: Penelusuran dan Catatan Mantan Anggota Pansus Hak Angket Bank Century DPR-RI (Where is Result of the Century?: Trajectory and Notes of a Former Member of Special Committees of Bank Century at the House), Jakarta: Yayasan Faham Indonesia, 2011.

5 Moerljarto Tjokrowinoto, Birokrasi Dalam Polemik (Birocracy in a Dispute), Yogyakarta: Total Media. 2009. 
name was even booming after the drama of his arrest was accompanied with a fake accident when his car hit an electricity pole to avoid arrest.

Previous research on corruption emphasizes that in most cases of corruption there are many parties who may be involved and committed by organizing white criminals. However, in certain cases, corruption may also be a result of maladministration and abuse of power. ${ }^{6}$

Given the huge number of corruptions that have been reported, evaluation of the steps to deal with the corruption in Indonesia is considered more necessary. Data from the Transparency International institution about quantitative standards to assess the level of perceptions of corruption in a country commonly referred to as CIP (Corruption Perception Index) shows that the problem of corruption in Indonesia is still complicated to properly be overcome. ${ }^{7}$ Even an institution such as the Indonesian National Police which also has its own special directorate to handle corruption is not free from the scandal involvement. This can be observed in the alleged corruption cases in the procurement of SIM (Driver License) simulators at Korlantas (Traffic Corps). What went worse was that corruption eradication has once triggered a conflict between the KPK and the Indonesian Police Criminal Investigation Unit due to different ways and approaches of handling the case. ${ }^{8}$

As described earlier in this article, corruption has affected lives

6 Ridwan Arifin, Wiki Oktama Putri. 'Penegakan Hukum Terhadap Anggota Legislatif dalam Kasus Tindak Pidana Korupsi di Indonesia’. Al Daulah: Jurnal Hukum Pidana dan Ketatanegaraan 8 (1), 2019, pp. 1-15; Ridwan Arifin, Devanda Prastiyo. 'Korupsi Kolektif (Korupsi Berjamaah) di Indonesia: Antara Faktor Penyebab dan Penegakan Hukum'. Jurnal Hukum Respublica, Vol. 18, No. 1, 2018, pp. 1- 13; Ridwan Arifin, Indah Sri Utari, Herry Subondo. 'Upaya Pengembalian Aset Korupsi Yang Berada Di Luar Negeri (Asset Recovery) Dalam Penegakan Hukum Pemberantasan Korupsi Di Indonesia’. IJCLS (Indonesian Journal of Criminal Law Studies), Vol. 1No. 1, 2016, pp. 105137. Doi: 10.15294 /ijcls.v1i1.10810

7 Klitgaard, R., Membasmi Korupsi (translated to Indonesian by Hermojo), Jakarta: Yayasan Obor Indonesia, 1998.

8 Susan Rose-Ackerman, Korupsi dan Pemerintahan (Corruption and Government), Jakarta: Pustaka Sinar Harapan, 2006. 
of almost every country in the world, especially Asian countries, and hampered their progress and development. To deal with corruption, every country applies its own way. Some countries are reported to have been successful in handling corruption, but others are still working hard to overcome such the problem. Hong Kong is perceived to have been successful to overcome the corruption in the country. Through its institution of Independent Commission Against Corruption (ICAC), Hong Kong has become a reference for many countries in the world as an example to have the most effective anti-corruption institution. Just like Indonesia, Hong Kong has a high level of corruption, but the ICAC successfully reduced corruption in Hong Kong in a short time and consistently maintained so. This happened because ICAC not only succeeded in eliminating many corruption cases but also changed the behavior of the people in Hong Kong. The ICAC has taken action and precautions against corruptors. A survey has been released showing that the ICAC is truly successful in handling corruption cases in Hong Kong."

As a comparative, corruption eradication in Indonesia and Hong Kong can be viewed not only from the working pattern of their eradication commission but also from the problem of corruption itself. In Indonesia, the corruption has been a symptom elsewhere and become a vicious circle among the community, especially as a result of political interest. The slogans of eradicating corruption, collusion, and nepotism are usually made during campaign for new leader of government. Yet, the expectation for corruption elimination in the country is still far from reality. ${ }^{10}$ In many times, the verbally commitment of eradicating corruption is nothing more than a political rhetoric from the political elites to earn sympathy and vote in the country. ${ }^{11}$ In Indonesia, an institution to be regarded as the most corrupt institution is the parliament. As the People's Representatives, their

9 Independent Commission Against Corruption (Hong Kong Special Administrative Region). 2007-2011 Annual Report. Hong Kong: Independent Commission Against Corruption. 2007-2011

10 Eddy Kristiyanto (ed), Etika Politik dalam Konteks Indonesia (The Ethics of Politics in Indonesian Context), Jakarta: Kanisius. 2001

11 Redatin Parwadi, Koruptologi (Corruptology), Yogyakarta: Kanisius. 2010 
disgraceful performances have created distrust among the people who viewed that the people's representatives are notorious of being inconsistence, liar, and corrupt. It is not something new in Indonesia to encounter in the last few years many of the people's representatives or MPR (People's Consultative Assembly), either in level I, level II and at the center have stumbled on this problem, some of whom have received verdicts at the court. ${ }^{12}$ Given the massive damage corruption may affect to the systemic life of the country, the government of Indonesia has taken critical steps to overcome the crime through a working pattern of the Corruption Eradication Commission which is an Indonesian Anti-Corruption institution. ${ }^{13}$

\section{B. Work Pattern for Eradicating Corruption by the KPK (Corruption Eradication Commission)}

\section{Background of the KPK and Corruption in Indonesia}

Historically speaking, before the formation of the KPK, the eradication of corruption in Indonesia was divided into three periods, namely the Old Order, the New Order and the Reform era. During the Old Order there were at least three attempts to eradicate corruption, one of which was the State Apparatus Retooling Committee (PARAN) which was formed under the law of the Emergency Situation Act. However, the PARAN failed to eradicate corruption because the corruptors actually took refuge under the president. Because of the ineffectiveness of this committee, PARAN was dispersed and replaced with Operation Budhi. ${ }^{14}$ The target of this new committee was to arrest corruptors in state-owned companies and judicial institutions.

12 Klitgaard, R., Maclean-Abaroa, R. and Parris, H.L. Penuntun Pemberantasan Korupsi Dalam Pemerintahan Daerah (A Guide to Corrution Eradication at the Regional Government), (translated into Indonesian by Masri Maris). Jakarta: Yayasan Obor Indonesia. 2002

13 Indonesia Corruption Watch. Independent Report, Corruption Assessment and Compliance United Nation Convention Against Corruption (UNCAC)-2003 in Indonesian Law. Jakarta: Indonesia Corruption Watch. 2008

14 Dennis Thomson F, Etika Politik Pejabat Negara (The Political Ethics of State Officials), Jakarta: Yayasan Obor Indonesia, 2002. 
The result was amazing. The Operation Budhi could save the country's finances in the amount of Rp. 11 billion. However, because it was considered to have disturbed the reputation of the president, the institution was dissolved and replaced with the High Command Retooling Revolutionary Apparatus (KOTBAR) led by President Soekarno himself. ${ }^{15}$

After Soekarno stepped down from his position and Indonesia entered the New Order era, there were three efforts to eradicate corruption carried out by the government. The first was the Corruption Eradication Team (TPK) chaired by the Attorney General with the assistance of the National Police Chief, ABRI Commander, and Minister of Justice, and was formed on 16 August 1967. In 1970 a Four-member Commission comprising figures like Mohammad Hatta, Anwar Tjokroaminoto, Herman Johannes, and Soetopo Yoewono was formed. However, the spirit of eradicating corruption is not apparent and eradicating corruption is not transparent. After Soeharto's term was over, Indonesia entered the Reform era with a new and more burning spirit. In 1999, the Law No. 31 of 1999 concerning the Eradication of Corruption Crimes was issued. ${ }^{16}$ In 2002, the Law No. 30 of 2002 regarding the KPK (Corruption Eradication Commission) was released. ${ }^{17}$

\section{The Working Pattern of the KPK}

The legal basis in eradicating corruption in Indonesia is quite a lot. There are more than 10 regulations either directly or indirectly ranging from TAP MPR, Laws, Government Regulations, Presidential Instructions, Presidential Decrees and Government Regulations. Of the many types of regulations, the most powerful legal basis is the Law. The following are the Laws related to combating corruption ${ }^{18}$ :

15 Romli Atmasasmita, Globalisasi dan Kejahatan Bisnis (Globalisation and Bussiness Crime), Jakarta: Kencana, 2010

16 Brantingham, P and Brantingham, P., Patterns in Crime. New York: Macmillan Publishing Company, 1984.

17 Boesono Soedarso, log.cit.

18 Komisi Pemberantasan Korupsi. Rencana Strategis Komisi Pemberantasan Korupsi Tahun 2011-2015. Jakarta: Komisi Pemberantasan Korupsi. 2011 
1) Law No. 30 of 2002 concerning the Corruption Eradication Commission

2) Law No.20 of 2001 concerning Eradication of Corruption Crimes

3) Law No.11 of 1980 concerning Anti Bribery

4) Law No.28 of 1999 concerning the Implementation of a Clean and Free State of Community Service

5) Law No.7 of 2006 concerning Ratification of the Anti-Corruption United Nations Convention

6) Law No.1 of 2006 concerning Reciprocal Assistance in Criminal Issues

The laws provide enormous power and authority for the KPK to supervise other state institutions with the task of eradicating corruption, conducting tapping, recording conversations and accessing bank records and taxes. In addition, the KPK also took over the handling of cases carried out at the Prosecutor's Office or the Police on the condition that in that case there was a delay in handling without clarity in handling the case, interfering with executive, judicial and legislative constraints and other matters The Prosecutor's Office or the Police are unable to handle the case. ${ }^{19}$

Based on Law No. 30 of 2002, it is learnt that the cases handled by the KPK includes two things; first, involving law enforcement officials, judicial officials, civil servants and related third parties; secondly, the corruption is more than one billion rupiahs of the state loses, which provoked public attention. ${ }^{20}$

19 Eddy Kristiyanto (ed), Log.cit.

20 Salam, Dharma Setyawan. Manajemen Pemerintah Indonesia (The Management of Indonesian Government) Jakarta: Djambatan. 2004, see also Law No. 30 of 2020 concerning Indonesian Corruption Eradication Commission, see the Explanation Appendix., it is stated that The authority of the Corruption Eradication Commission in conducting investigations, investigations and prosecution of corruption includes corruption which: (a) involves law enforcement officials, state administrators, and other people who are related with criminal acts of corruption committed by law enforcement officials or state administrators; (b). get disturbing attention from the public; and/or (c). concerning state losses of at least Rp. 1,000,000,000.00 (one billion rupiah) 
In an effort to reduce bureaucratic corruption at the regional level, the KPK has eleven priorities as coordination and supervision, namely immigration, defense, SIM services, STNK services, Transportation Agency, Integrated Service Office, Cooperative and Industry and Trade Office, Population and Civil Registry Service, Inspectorate and regional public hospitals. This was conducted in collaboration with many relevant agencies. To promote regional development, the $\mathrm{KPK}$ also built an Integrity Zone such as a corruption-free regional development programs. ${ }^{21}$ The Integrity Zone is also an area developed as a manifestation of the implementation of concrete efforts in the prevention and elimination of corruption. With the establishment of this Integrity Zone each city government can freely submit its territory to a Corruption Free Area. The Integrity Fair is an exhibition that aims to campaign the integrity values as an effort to prevent and eradicate corruption. ${ }^{22}$ This exhibition has been carried out in various cities and the effort aiming to invite regional governments to work together to prevent and eradicate corruption.

In addition to the establishment of Integrity Zone, the effort to deal with corruption in the business sector, the KPK also implemented the Anti-Corruption Initiative Study Program (SPAK), which is an assessment of the business sector. To assess the performance of the corruption eradication in Indonesia, the KPK has the privilege among the Corruption Penalty Court in the Indonesian justice system. Therefore, in carrying out its authority, the KPK has to be in touch with other institutions which also have same authority, for example, with the Attorney General Office, the Police, the State Intelligence Agency, Bank Indonesia, etc. ${ }^{23}$ If there are no clear rules in the

21 Nur Basuki Minarno, Penyalahgunaan Wewenang dan Tindak Pidana Korupsi Dalam Pengelolaan Keuangan Daerah (Authority Abuse and Corruption Crime in the Management of Regional Budget) Yogyakarta: Laksbang Mediatama, 2009

22 Kompas, “Wacana Penanganan Terhadap Pelaku Korupsi,” Kompas, Jakarta, 16 June 2011, also see Puji Astuti, POLITIK KORUPSI : Kendala Sistemik Pemberantasan Korupsi di Indonesia, Politika: Jurnal Ilmu Politik, Vol. 2 No. 1, 2011, pp. 5-17.

23 Krisna Harahap, Pemberantasan Korupsi di Indonesia Jalan Tiada Ujung (The Corruption Eradication in Indonesia: A Road with No End), 
law regarding sanctions and coordination procedures between these institutions, the KPK's task in carrying out eradication of corruption will be hampered.

\section{Corruption Eradication by the ICAC}

\section{ICAC Background and Corruption in Hong Kong}

The legal system in Hong Kong is different from the one in any other countries. The legal system performed by this country is based on the Chinese Republic's Constitution, which is an area with the principle of one country, two systems that have a Basic Law. The Basic Law itself regulates general principles, relations between the central government in Beijing and Hong Kong, basic rights and obligations of the population, economic structure, education, science, politics, sports, religion, labor, social work, culture, interpretation, foreign problems and changes to Basic Law, as well as additional provisions. Hong Kong is a country that has the lowest level of corruption in the world, Hong Kong Police Agency is widely perceived as the most effective and corrupt-free police agency in Asia. ${ }^{24}$

Historically speaking, long before, Hong Kong experienced a situation when corruptors were rampant. The most prolific corruption was committed by the police agencies. Circulating drugs, gambling and prostitution, and traffic violations were among the main crimes the police used to get involved at the time. Then in the early 1970 s the community began asking the government to talk about corruption and established an anti-corruption institution called ICAC.

ICAC was established to reduce corruption in Hong Kong. In eradicating corruption in Hong Kong, ICAC focuses on three major responsibilities, known as the 'Three-Pronged" strategy namely enforcement, education, and prevention. These three main tasks focus

Bandung: Grafiti. 2009

24 Lembaga Administrasi Negara, Strategi Penanganan Korupsi di Negara-Negara Asia Pasifik (The Strategy of Handling Corruption in Asia Pacific Countries), Jakarta: LAN, 2007. 
are contained in three departments within the ICAC organizational structure:

1) Operation Department

2) Corruption Prevention Department

3) Community Relations Department

In addition to the three departments, there is an Administration Branch whose duty is to serve the three departments in administration and staffing. These things are strategies implemented by each department.

\section{ICAC Working Pattern}

Consistently, ICAC continues to adopt its strategy in three phases. The first phase is building trust and legislation; the second is the provision of services and information, and the third phase is prioritizing leadership, ownership, and partnership. From the beginning of 1974 to the 1980s the ICAC had handled high-profile cases and succeeded in completing this mission resulting in higher trust of the community towards this institution. ${ }^{25}$ In carrying out its work, the ICAC has a clear constitutional foundation which consists of three regulations. The first regulation is the Independent Commission against Corruption Ordinance which contains the authority of commissioners, investigator authority, parameters for conducting investigations, procedures for suspects and evidence, and other ICAC authorities. The second is The Prevention of the Bribery Ordinance, namely defining specifically about bribery involving public services, public bodies, and private or private sector employees. And this regulation confirms ICAC to dismantle and identify transactions and assets disguised by corrupt practices. The third is a regulation to maintain the confidentiality of ICAC investigative activities. ${ }^{26}$

Every year the ICAC has a document (ICAC Annual Report)

25 Independent Commission Against Corruption (Hong Kong). "ICAC Annual Survey 2011, Executive Summary” http://www.icac.org.hk/new_icac/ eng/about/history/main_2.html (retrived on 13 November 2012)

26 United Nations, United Nations Convention Against Corruption, New York: United Nations, 2012 
that is published with the contents of an explanation of the objective policies that are implemented. In the document there are four points, namely:

1) Policy Objective, contains the final results that must be achieved by a program and the results which have already been achieved;

2) Key Result Areas, contains an explanation of the elements needed to realize policy objectives and progress that has been achieved;

3) Indicators, contains an explanation of the specific steps taken to achieve results in key result areas;

4) Initiatives, contains an explanation of the specific steps taken to achieve the results in the key result areas and targets achieved or will be achieved. ${ }^{27}$

The report is a form of transparency of the ICAC investigations which are opened publicly to give the people access to know what the ICAC has done and let them give assessment towards its performance. ${ }^{28}$ The cases handled in the ICAC are divided into four stages of settlement. The first is reporting stage. The second is investigation phase. The third is investigation. The fourth is prosecution. Not only that, the ICAC has an intelligence agency to detect acts of corruption.

Apart from the comparison of the working patterns of eradicating corruption by the Indonesian Corruption Eradication Commission and the Independent Commission Against Corruption, the strategy for combating corruption does not only use legal approaches (penal approach/criminal law) but non-penal approaches. The nonpenal approach in preventing corruption besides the criminal path (strict law enforcement) is carried out because criminal law cannot reach its criminological factor and this legal approach aims to improve systematically so that it is repressive, while the non-penal approach aims to correct the cause by making preventive measures that

27 Independent Commission Against Corruption (Hong Kong). "Legal Empowerment” http://www.icac.org.hk/en/about_icac/le.index.html (retrieved on 18th November 2012)

28 Transparency International, Corruption Penerbit Index 2011, Transparency International. 2011 
are preventive. Which is a criminal law approach mean an approach using criminal law as a tool for the political legal approach. ${ }^{29}$

And this legal politics is a legal policy that will be implemented nationally by the Indonesian government. This legal politics consists of:

1) Development of a law that contains the making and renewal of the law on legal materials so that they can be in accordance with their needs,

2) Implementation of existing legal provisions including in the affirmation of the functions of the institution and the guidance of law enforcers. ${ }^{30}$

In the political perspective of criminal law, these efforts include the establishment of criminal law provisions and implementing the provisions of criminal law. Contrary to this, the political law criminal approach to eradicating corruption must have formal criminal law and material criminal law, and the implementation of all legal instruments must be supported by public awareness and compliance. ${ }^{31}$ The loss of corrupt actions in Indonesia is not only based on the good or bad of the applicable laws, but also on human morality and the legal culture of society.

\section{Conclusion}

Based on a comparative approache, it can be concluded that from the disscussion, as long as the working patterns of the ICAC and the KPK are concerned, there are some differences that make ICAC able to eradicate corruption in Hong Kong which is more effective than the KPK in Indonesia. In terms of legal basis, ICAC has the advantages than that of the KPK. The law used by the ICAC is more effective so it does not create legal loopholes and obstacles for those who run it. Besides, ICAC's strategy of implementation focuses on

29 Andi Hamzah, Pemberantasan Korupsi di Berbagai Negara (Corruption Eradication in Various Countries), Jakarta: Sinar Grafika, 2005

30 JSSCS GovHK. "Chapter 10 ICAC Overview” www.jsscs.gov.hk/.../gs_ch10. $p d f$ (accessed on $9^{\text {th }}$ December 2012)

31 Lembaga Administrasi Negara, Log.Cit. 
the root of the problem, the one that the KPK fails apply. While the ICAC has the advantage of being more focused and efficient because it has been attached to the department that has been determined, the KPK's strategic and long-term plans have always been changing and have not running continuously. These differences in work patterns have clearly reflected from the CPI survey by Transparency International, which places Indonesia at the top in the list of the most corrupt countries while Hong Kong in the ranks of free corrupt countries. Furthermore, it is also highlighted that the government of Indonesia has implemented a policy of renewal and establishment of laws regarding the eradication of corruption criminal acts which prescribe severe criminal sanctions. Yet the government has not made satisfactory improvements to the institutional structure of government administrators. To learnt from the study abobve, combatting corruption is not only a matter of criminal sanctions, but also about the improvement of quality, quantity and morale of the state administration. A comprhensive approach is always necessary in order to eradicate corruption radically.

\section{Bibliography}

\section{Legal document}

Indonesia, Undang-Undang Nomor 30 Tahun 2002 tentang Komisi Pemberatantasan Tindak Pidana Korupsi (Law No. 30 of 2002 concerning Indonesian Corruption Eradication Commission)

\section{Books and Journals}

Arifin, Ridwan \& Wiki Oktama Putri, 2019, "Penegakan Hukum Terhadap Anggota Legislatif dalam Kasus Tindak Pidana Korupsi di Indonesia." Al Daulah: Jurnal Hukum Pidana dan Ketatanegaraan 8 (1).

Arifin, Ridwan \& Devanda Prastiyo, 2018, "Korupsi Kolektif (Korupsi Berjamaah) di Indonesia: Antara Faktor Penyebab dan Penegakan Hukum.” Jurnal Hukum Respublica, Vol. 18, No. 1.

Arifin, Ridwan \& Indah Sri Utari \& Herry Subondo, 2016, "Upaya 
Pengembalian Aset Korupsi Yang Berada Di Luar Negeri (Asset Recovery) Dalam Penegakan Hukum Pemberantasan Korupsi Di Indonesia.” IJCLS (Indonesian Journal of Criminal Law Studies), Vol. 1No. 1,

Astuti, Puji, 2011, "POLITIK KORUPSI : Kendala Sistemik Pemberantasan Korupsi di Indonesia," Politika: Jurnal Ilmu Politik, Vol. 2 No. 1.

Atmasasmita, Romli, 2010, Globalisasi dan Kejahatan Bisnis (Globalisation and Bussiness Crime), Jakarta: Kencana

Brantingham, P and Brantingham, P., 1984, Patterns in Crime. New York: Macmillan Publishing Company.

Andi Hamzah, 2005, Pemberantasan Korupsi di Berbagai Negara (Corruption Eradication in Various Countries), Jakarta: Sinar Grafika.

Hamzah, Fahri, 2011, Kemana Ujung Century?: Penelusuran dan Catatan Mantan Anggota Pansus Hak Angket Bank Century DPR-RI (Where is Result of the Century?: Trajectory and Notes of a Former Member of Special Committees of Bank Century at the House), Jakarta: Yayasan Faham Indonesia.

Hamzah, Fahri, 2012, Demokrasi, Transisi, Korupsi (Democracy, Transition, Corruption), Jakarta: Gudang Penerbit.

Independent Commission Against Corruption (Hong Kong Special Administrative Region). 2007-2011 Annual Report. Hong Kong: Independent Commission Against Corruption. 2007-2011

Indonesia Corruption Watch. 2008, Independent Report, Corruption Assessment and Compliance United Nation Convention Against Corruption (UNCAC)-2003 in Indonesian Law. Jakarta: Indonesia Corruption Watch.

Harahap, Krisna, 2009, Pemberantasan Korupsi di Indonesia Jalan Tiada Ujung (The Corruption Eradication in Indonesia: A Road with No End), Bandung: Grafiti.

Kharismadohan, Alif, 2019, "Mens Rea and State Loses on Corruption Cases: An Analysis of Corruption Court Judgment of Semarang." Journal of Law and Legal Reform, 1(1).

Klitgaard, R., 1998, Membasmi Korupsi (translated to Indonesian by 
Hermojo), Jakarta: Yayasan Obor Indonesia.

Klitgaard, R., Maclean-Abaroa, R. and Parris, H.L. 2002, Penuntun

Pemberantasan Korupsi Dalam Pemerintahan Daerah (A Guide to Corrution Eradication at the Regional Government), (translated into Indonesian by Masri Maris). Jakarta: Yayasan Obor Indonesia.

Komisi Pemberantasan Korupsi, 2006, Memahami Untuk Membasmi (Understanding to Eradicate), Jakarta: Komisi Pemberantasan Korupsi.

Komisi Pemberantasan Korupsi, 2011, Rencana Strategis Komisi Pemberantasan Korupsi Tahun 2011-2015. Jakarta: Komisi Pemberantasan Korupsi.

Kompas, 2011, "Wacana Penanganan Terhadap Pelaku Korupsi," Kompas, Jakarta, 16 June 2011,

Kristiyanto, Eddy (ed), 2001, Etika Politik dalam Konteks Indonesia (The Ethics of Politics in Indonesian Context), Jakarta: Kanisius.

Lembaga Administrasi Negara, 2007, Strategi Penanganan Korupsi di Negara-Negara Asia Pasifik (The Strategy of Handling Corruption in Asia Pacific Countries), Jakarta: LAN.

Minarno, Nur Basuki, 2009, Penyalahgunaan Wewenang dan Tindak Pidana Korupsi Dalam Pengelolaan Keuangan Daerah (Authority Abuse and Corruption Crime in the Management of Regional Budget) Yogyakarta: Laksbang Mediatama.

Pamungkas, Djoko, 2019, "How Police Overcomes Money Laundering? Study Analysis of Role of Central Java Regional Police Department on Money Laundering Case.” Journal of Law and Legal Reform. 1(1).

Redatin Parwadi, 2010, Koruptologi (Corruptology), Yogyakarta: Kanisius.

Rose, Ackerman, Susan, 2006, Korupsi dan Pemerintahan (Corruption and Government), Jakarta: Pustaka Sinar Harapan.

Soedarso, Boesono, 2009, Latar Belakang Sejarah dan Kultural Korupsi di Indonesia (The Historical and Cultural Background of Corruption in Indonesia), Jakarta: Universitas Indonesia, 2009.

Salam, Dharma Setyawan. 2004, Manajemen Pemerintah Indonesia 
(The Management of Indonesian Government) Jakarta: Djambatan. 2004.

Tjokrowinoto, Moerljarto, 2009, Birokrasi Dalam Polemik (Birocracy in a Dispute), Yogyakarta: Total Media.

Thomson, Dennis F., 2002, Etika Politik Pejabat Negara (Political Ethics and State Office), Jakarta: Yayasan Obor Indonesia, 2002.

United Nations, 2012, United Nations Convention Against Corruption, New York: United Nations.

\section{Websites}

Independent Commission Against Corruption (Hong Kong). "ICAC Annual Survey 2011, Executive Summary" http://www.icac. org.hk/new_icac/eng/about/history/main_2.html (retrived on 13 November 2012)

Independent Commission Against Corruption (Hong Kong). "Legal Empowerment” http://www.icac.org.hk/en/about_icac/ le.index.html (retrieved on 18th November 2012)

JSSCS GovHK. "Chapter 10 ICAC Overview” www.jsscs.gov.hk/ .../ gs_ch10.pdf (accessed on 9th December 2012)

Transparency International, 2011, Corruption Penerbit Index 2011, Transparency International. 